\title{
Uticaj istorijskih i političkih promena na razvoj naselja u dva posavska predela od 18 . veka do danas
}

\author{
Stojanka Radulović \\ Šumarski fakultet Univerziteta u Beogradu, Odsek za pejzažnu arhitekturu i hortikulturu, \\ Beograd, Srbija \\ e-mail: stojanka.radulovic@sfb.bg.ac.rs
}

\author{
Aleksandar Bobić \\ Šumarksi i Arhitektonski fakultet Univerziteta u Beogradu, Beograd, Srbija \\ e-mail:aleksandar.bobic@sfb.bg.ac.rs
}

Mirjana Sekulić

Fakultet tehničkih nauka Univerziteta u Novom Sadu, Departman za arhitekturu i urbanizam, Novi Sad, Srbija

e-mail:sekulic.mijana55@gmail.com

\author{
Martin Bobinac \\ Šumarski fakultet Univerziteta u Beogradu, Beograd, Srbija \\ e-mail:martin.bobinac@sfb.bg.ac.rs
}

SAŽETAK U radu je istraživan uticaj istorijskih i političkih promena na razvoj naselja u posavskim predelima na prostoru današnje Srbije u vremenskom opsegu od 18. veka do danas. Analizirana je transformacija, po prirodnim karakteristikama i etničkom sastavu, dva slična predela - donjeg Srema i obrenovačke Posavine, ali i veoma različita, po istorijski uspostavljenim kulturnim i društvenim vrednostima Otomanskog i Austrijskog (AustroUgarskog) političkog uticaja.

Fokus rada predstavlja komparativna i kontrastivna analiza planova, regulativa, planerskih praksi i ključnih istorijskih i političkih događaja vezanih za posmatranu teritoriju od 18. veka do danas. U istraživanju se došlo do zaključka da su tokom reurbanizacije naselja na posmatranoj teritoriji uspostavljena dva, međusobno različita i prepoznatljiva prostorna obrasca, posebnih osobenosti i razlika u pogledu topografije i organizacije, koji su se kao takvi uglavnom zadržali do danas, bez obzira na istovetnost društvenog i političkog poretka tokom 20. veka. Zaključeno je da je viši stepen uređenosti naselja u jednom predelu u odnosu na drugi postignut, između ostalog, formiranjem šire prostorne infrastrukture i regulacije naselja - mreže ulica i neizgrađenih blokova, što je omogućilo da se kroz vreme upravlja razvojem naselja i spreči spontana izgradnja. Međutim, u periodu tranzicije političkog i ekonomskog sistema Srbije u predelu se intenzivirala bespravna izgradnja u pojavnom obliku tzv. naselja uz put, bez obzira na uspostavljene vrednosti i tradicije načina života. Zato se može zaključiti da je naglo i mehaničko povećanje stanovništva u drugoj polovini 20. veka, zajedno sa nedostatkom stanova $\mathrm{i} / \mathrm{ili}$ nepostojanjem tržišta stanova, te nepostojanje planova i/ili nepoštovanje planske regulative, te nizak stepen društvene održivosti ostavilo posledice na predeo, jer sistem u obliku slabe državne kontrole reda i zakonitosti u pogledu aktivnosti čoveka i relevantnih aktera na posmatranom području, nije uspeo da se odupre stihijskom širenju naselja.

Ključne reči: predeo, spontanost, naselje, prostorni obrazac, društvena vrednost.

Copyright (C) 2012 Institut za društvena istraživanja u Zagrebu - Institute for Social Research in Zagreb Sva prava pridržana - All rights reserved 


\section{Uvod}

Društveni uticaj na određeni predeo je obično prostorno mnogo širi i mogao bi se tako posmatrati. Međutim, društveni uticaj je vrlo često podložan različitim modifikacijama kao posledica određenog prilagođavanja koje je u vezi sa prirodnim karakteristikama tog predela. Dalje, kroz vreme modifikuju se prirodne karakteristike, ali ostaju elementi predela (npr. naselja) kao posledica specifičnosti nekog drugog vremena ili bitnog društvenog događaja (Stephenson, 2008.; Antrop, 2005.). Posmatrajući različite procese kroz prostor - vreme često se uočava raskorak između stanja sredine (Životne i društvene) i postojećih elemenata - strukture predela. Struktura utiče na funkcionisanje predela pa se shodno tome može postaviti pitanje kako npr., naselja nastala u jednom drugom vremenu utiču na funkcionisanje predela $\mathrm{u}$ sadašnjem vremenu ili obrnuto, kako su promene u društvu i promene u matrici predela uticale na transformaciju naselja (Van Eetvelde and Antrop, 2009.; Forman and Godron, 1986.)?

U Srbiji je period tranzicije političkog sistema, u veoma kratkom periodu doveo do velikih društvenih promena izazvanih političkom i ekonomskom krizom, ratovima i velikim migracijama stanovništva. Ovi kompleksni politički i društveni procesi su očekivano doveli do slabljenja državne kontrole u sferi sprovođenja složene planerske regulative, što je za posledicu imalo izraženiju pojavu već više-manje ustaljene prakse besprvane izgradnje što za posledicu po pravilu ima spontano i često stihijsko širenje naselja (Kristiánová and Adamková, 2010.; Simon, 1973.). Na predeonom nivou ovi procesi se mogu razumeti kao osnova za generisanje različitih prostornih obrazaca. Iz ovog sledi polazna teza ovog rada da su promene u društvu različito uticale na transformaciju naselja u dva posavska predela, sa sličnim prirodnim karakteristikama, sa sličnim etničkim sastavom stanovništva, kao i sa sličnom dispozicijom u odnosu na Beograd. Objašnjenje ovakvog različitog uticaja na promene naselja u ova dva predela nalazimo u nivou njihovog stepena uređenosti, formi, organizaciji, tradiciji i funkcionisanju. U kontekstu ovako opisanih promena cilj rada je da utvrdi kako su različiti društveni uslovi i politički događaji kroz istoriju, uticali na prostornu transformaciju naselja u dva susedna po prirodnim i etničkim karakteristikama, slična predela.

\section{Metod}

Osnovni metod istraživanja je uporedna analiza dokumenata vezanih za dva posavska predela na prostoru današnje Srbije - donjeg Srema i obrenovačke Posavine u periodu od 18 do 21. veka. Korišćene su topografske karte razmere 1:75.000 iz 1881. (1897.) i 1:50.000 iz 1935., kao i satelitski snimci iz 2006., zatim opisi putopisaca, kao i faktografska građa vezana za glavne reforme društvenog i političkog sistema $\mathrm{u}$ istraživanim posavskim predelima. Analiza naselja, tačnije njihovog građevinskog reona i samog predela apstrahovanih na nivo šeme, tabele i obrasca, treba da utvrdi prostorne promene izazvane važnim istorijskim i političkim uticajima. 
Problem neujednačene detaljnosti karata iz različitog perioda rešen je tako što su karte svedene na istu graničnu razmeru 1:75.000. Preko prostornih obrazaca bilo je moguće, kroz vreme u oba posmatrana predela, izvršiti uporednu analizu naselja, dok se u okviru jednog vremenskog preseka vršilo kontrastiranje naselja dva različita predela po suprotnostima. Rezultati analize su zatim upoređivani sa dominantnim društvenim i političkim fenomenima koji su im prethodili kako bi se proverila teza o njihovom uticaju na transformaciju predela i naselja.

Predeli analiziranih naselja istraživani su kroz tri vremenska preseka (krajem 19. veka, 1935. i 2006.). Izdvajanje predela zasnovano je na strukturnim karakteristikama pokrivača tla u okviru tipa reljefa i klimatskog regiona (Forman and Godron, 1986.). Korišćene su varijable kao što su tip, veličina i prostorni raspored elemenata predela. Klasifikacija po stepenu antropogene modifikacije je omogućila da se može govoriti o podtipovima odrecenih predela u okviru promena kroz istoriju od prirodi bliskog do suburbanog predela. preko kartografskog materijala i pisane građe generalno su analizirani struktura i osnovni prostorni procesi u svakom vremenskom preseku. na osnovu tako dobijenih rezultata komentarisane su prostorne transformacije i zaključivano je o izdvojenim predelima.

\section{Prostor istraživanja}

\subsection{Položaj i prirodne karakteristike}

Istraživani predeli nalaze se u blizini Beograda na levoj i desnoj obali reke Save na rečnoj terasi (Menković i Košćel, 2003.) (slika 1.). Prostor predstavlja ravničarski reljef izgrađen od mikroblika - dolina potoka, greda i udolina. Predeo donjeg Srema nalazi se na levoj obali reke Save na terasi prekrivenoj pretaloženim lesom. Takav les u sinergiji sa uticajem podzemne i poplavne vode daje teška i slabo propusna zemljišta. Rezultat navedenih uzročno-posledičnih odnosa, pogotovu kada se ukloni šuma, je pojava velikog broja ritova i bara. preko reke, na desnoj obali Save nalazi se predeo obrenovačke Posavine. rečna terasa u ovom predelu je bez pretaloženog lesa, što čini zemljišta propusnim, a pojavu vlažnih terena u dubljim udolinama (depresijama).

Područje istraživanja pripada klimatskom regionu kontinentalnog tipa - panonska klima (Metzger i dr., 2005.). To znači da bi panonske klimatske osobine kontrolisale prirodne procese u oba predela da nema uticaja podzemnih i poplavnih voda. Međutim, klimatske osobine su došle do izražaja tek kada je kroz vreme, bila završena izgradnja mreže kanala. Kanali su spustili nivo podzemnih voda, a nasipi podignuti u susednom aluvijalnom predelu su zaustavli visoke nivoe plavne vode reke Save. 
Slika 1.

Geografski položaj i granice dva posavska predela

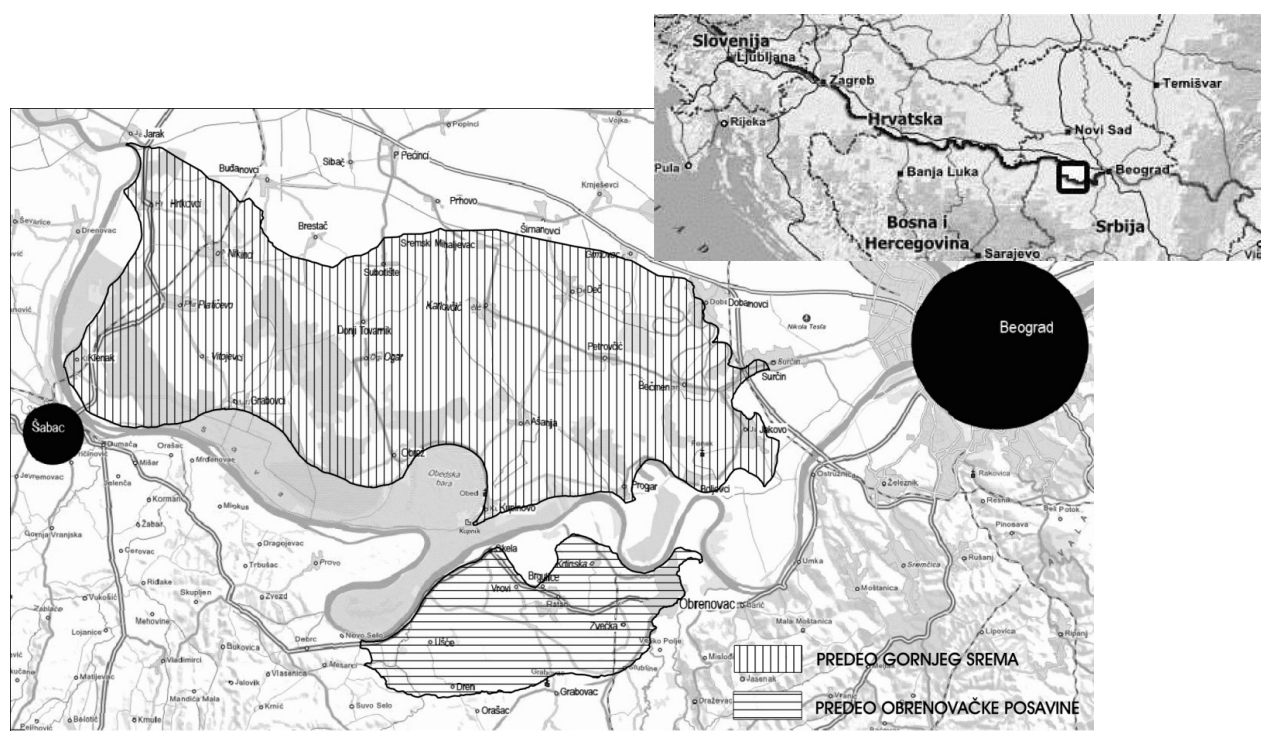

Izvor: http://www.serbiamap.net/index en.html

U vreme dominiranja prirodnih, higrofilnih uslova najrasprostranjeniji vegetacijski pokrivač u ovoj ravnici je bio u okviru bioma južnoevropskih listopadnih šuma vodoplavnog i nizijskog tipa (Matvejev i Puncer, 1989.) i pripadao je šumi pre svih, lužnjaka i graba. Na prevlažnom terenu za pojavu šume javljale su se žbunaste formacije, higrofilna i hidrofilna zeljasta vegetacija najčešce, u blizini otvorenih vodenih okana.

Nazivi predela su povezani sa njihovim položajem odnosno, nazivima širih geografskih celina.

\subsection{Istorijske i političke karakteristike}

U 17. veku u ovom delu Posavine, sa jedne i druge strane reke, vladaju Turci (grafikon 1.). U to vreme teritorija Posavine je opustošena ratnim razaranjima, što je za posledicu imalo nastanak „pustara“, ali i proređenost stanovništva, pa samim tim i nestalnost njegovog stanovanja, odnosno veličine i dužine trajanja pojedinih naselja. Stanovništvo živi u zemunicama ili kolibama kako bi, kada zatreba, moglo lako da se preseli na drugo mesto (Popović i Sečanski, 1936.). Razloge za ovako ponašanje treba tražiti kako u izbegavanju ratnih sukoba, tako i u izbegavanju plaćanja poreza. Posle proterivanja Turaka, na teritoriji Srema (od 1718.) austrijske vlasti uspostavljaju komorsko-spahijski sistem i graničarski sistem (1745. - 1881.). Donesen je niz pravnih akata među kojima i Stalni slavonski urbar 1756. kao osnovni preduslov za naseljavanje, obnovu i uređenje prostora kako bi stanovništvo i prirodne resurse, 
između ostaloga, stavila u funkciju održavanja vojne granice. Na prostorima desne strane reke - posavske (i podunavske) Srbije, u tom periodu se nastavljaju ratna razaranja, dolaziće do smene turskog i austrijskog suvereniteta, sve do početka 19. veka (Krstić, 2005.), kada Drugi srpski ustanak donosi autonomiju od turske vlasti.

Grafikon 1.

Pregled društveno - političkih promena od 18. veka do danas u dva posavska predela

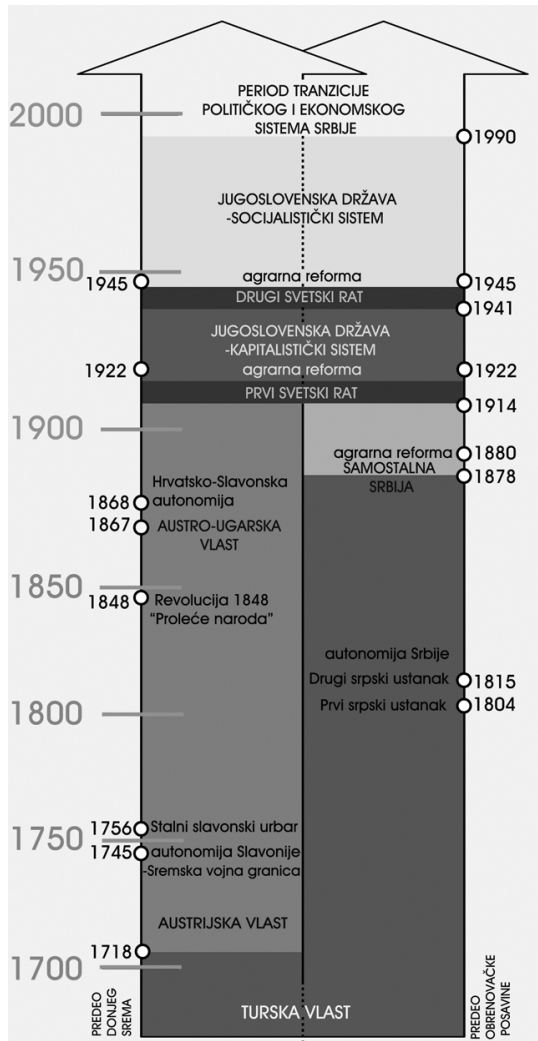

Jedno od središnjih mesta u razumevanju društvenih i političkih uticaja na transformaciju istraživanih predela predstavljaju agrarne reforme shvaćene kao „voljno delovanje institucija državne vlasti u oblasti agrara u pogledu načina obrade zemljišta, njegovog korišćenja, ali pre svega u smislu svojinskih odnosa nad zemljom“1. Agrarno pitanje bilo je i ostalo jedno od središnjih pitanja razvoja dominantno agrarnog društva kakvo je bilo kroz istoriju do danas društvo na prostoru današnje Srbije. S druge strane, svaka se agrarna reforma fundamentalno bavila naseljavanjem i raseljavanjem stanovništva u skladu sa trenutnim političkim interesima vlade. Kao osnovne društvene, pa samim tim i vrednosne promene koje su uticale na transformaciju predela i naselja na posmatranom području prepoznato je nekoliko važnih formalnih i neformalnih agrarnih reformi.

1 cit., Milošević, S., 2008., str. 50. 
„Prva agrarna reforma“ na analiziranom području Srema doneta je u vidu „Stalnog slavonskog urbara“ Marije Terezije iz 1756., kao potreba za konsolidacijom administrativne vlasti i poboljšanje vojne, političke i finansijske pozicije države (Krueger, 2002.). „Methodus urbarialis” bio je primenjivan u tadašnjem civilnom delu Srema - u Sremskoj županiji (Gavrilović, 1960.). U vojnoj granici Austrijska carevina je podržavala formiranje graničarskih kućnih zadruga jer su bile najpogodniji i najjeftiniji način za održavanje vojne granice, kao odbrambenog prostora prema Osmanskom carstvu. Predeo donjeg Srema pripadao je graničarskom delu Srema gde je celokupni društveni i privredni život bio je podvrgnut vojnim interesima. Privreda se sastojala od stočarstva, ratarstva, ribolova i trgovine, ali su neuporedivo najbolji uslovi bili za razvoj stočarstva jer su graničarska naselja raspolagala pašnjacima i pustarskim zemljištima koje je idavano u zakup (Gavrilović, 2005.). U vojnoj granici, proces razvojničenja, odnosno izjednačavanje sa civilnim Sremom u oblasti zemljišnih i posedovnih odnosa tekao je preko sistema lena i uživalačkih prava, a zatim vlasništva kućnih zadruga na zemljišni posed (Gaćeša, 2007.; Roksandić, 2007.; Kulauzov, 2008.).

Za razliku od prostora današnjeg Srema na kome je Austrija u drugoj polovini 18. veka započela i sprovela suštinske reforme u redefinisanju agrarnih odnosa i uređenja naselja, na prostoru današnje centralne Srbije se na takve reforme čekalo još gotovo ceo vek. Početkom 19. veka Srbija je bila ustrojena kroz organizacione jedinice nahije, knežine i srezove pod turskom upravom. U to vreme, većina stanovnika je živela na selu u okviru patrijarhalnih zadruga kao glavnog nosioca spahijskih produkcionih odnosa. Prvi korak ka početku reforme i može se reći modernizaciji predstavlja opštenarodni ustanak (1804.) koji je pored oslobodilačke imao i sve karakteristike velike socijalno-ekonomske i političko-nacionalne revolucije (Jovančević, 2010.). tek posle Drugog srpskog ustanka 1815., dolazi do suštinskog raspada turskih spahiluka. Sledi veliki priliv stanovništva, državno-pravne reforme ${ }^{2}$ koje konačno rezultiraju napuštanjem feudalnih odnosa. Međutim, posed je usitnjen - prema popisu iz 1897. godine veličina zemljišnog poseda po vlasniku je 1-2 hektara (Bogojević, 1928.) pa vlada veliko siromaštvo. Razvoj naselja u ovom periodu, na području obrenovačke posavine prate promene u društvu, pa se od izolovanih kuća i raštrkanih naselja po šumama i potocima nastoje formirati zbijenije i grupisanije naseobine. Tim povodom izdaje se niz akata, uredbi, odredbi i sl., među kojima i prvi pravni akt „Uredba o ušoravanju naselja“ iz 1837. (Maksimović, 1962.), koja je sprovedena u Mačvi, a u drugim delovima zemlje sporadično (Simonović i Ribar, 1993.).

Period ratova 1912.-1918. Srbiju je obeležio drastičnim gubitkom stanovništva i velikim ekonomskim osiromašenjem. Formirana je nova država tako da istraživani predeli pripadaju istom političkom uticaju. Agrarna reforma 1922. godine imala je za cilj uspostavljanje pravednijih zemljišno-posedovnih odnosa što je vodilo, između ostalog, ukidanju krupnih zemljišnih poseda. Eksproprijacija zemljišta je mnogo više pogodila severne krajeve koji su u prethodnom periodu bili pod Hasburškom monarhijom, nego prostor centralne Srbije u kojoj su već bili usitnjeni posedi. U

\footnotetext{
2 Sretenjski ustav 1835., odnosno Turski ustav 1838., kao i Berlinski kongres 1878.
} 
narednom periodu, do Drugog svetskog rata, na istraživanom području, u Predelu donjeg Srema da bi se sprečilo dalje usitnjavanje poseda i stvorili uslovi za intenzivniju proizvodnju izvršene su prve komasacije. Predmet grupisanja poseda bile su većinom oranice, ali i neki dugi oblici načina korišćenja zemlje, ali ne i naselja. Komasacijom nisu bili obuhvaćeni celi atari. U ovom periodu u Predelu obrenovačke Posavine, kao i u drugim delovima centralne Srbije zbog nedostatka premera i katastra zemljišta ukrupnjavanje poseda nije bilo moguće sprovoditi.

Odmah nakon Drugog svetskog rata u razorenoj Jugoslaviji donosi se Zakon o agrarnoj reformi i kolonizaciji 1945. godine kojim se redefinišu predratni i ratni odnosi u skladu sa socijalističkim uređenjem zemlje. Zakonom se predviđa eksproprijacija velikih zemljišnih poseda, tako da je očekivani rezultat između ostalog usitnjavanje poseda. Tek su od 1956. godine počeli ponovo da se realizuju projekti komasacije na inicijativu velikih poljoprivrednih gazdinstava kojima je ovakva mera omogućavala efikasniju proizvodnju (RGZ, 2003.). Uspostavljanjem pravne regulative (od 1974.) komasacija je mogla da se realizuje na široj teritoriji Srbije. Za razliku od drugih zemalja u tranziciji, Srbija ima tradiciju u komasaciji, ali za razliku od razvijenijih zemalja nije postojala veza između komasacije i planova za uređenje naselja (Đokić and Marošan, 2008.).

Po raspadu SFR Jugoslavije u poslednjoj deceniji 20. veka Srbija upada u duboku društvenu, političku i ekonomsku krizu čije se posledice osećaju do danas. Agrarno pitanje je i dalje ostalo nerešeno, čak mnogo više produbljeno nego ranije, s obzirom da se i dalje odvija aktuelna tranzicija društvenog, političkog i ekonomskog sistema zemlje. U tom smislu, od procesa tranzicije se očekuje prilagođavanje novim kapitalističkim odnosima i ispunjenje ciljeva u pogledu reforme institucija, restrukturiranja, demonopolizacije i privatizacije poljoprivrede, ukrupnjivanje poseda i prilagođavanje standardima Evropske unije (Pejanović i Tica, 2005.). Nedovoljno razvijeni i prilagođeni ekonomski i pravni okviri za razvoj društva, te posledice ratova u pogledu velike migracije stanovništva sa prostora Hrvatske i Bosne i Hercegovine mahom na područje Vojvodine ${ }^{3}$, siromaštvo i nedovoljna motivisanost seoskog stanovništva su samo od nekih dominantnih uticaja na korišćenje zemlje i organizaciju naselja koje u najvećoj meri karakteriše stihija i spontanost.

3 Na području Srema pa tako i na njegovom donjem delu, zabeležen je veliki priliv izbeglica. Jedan od razloga su rođaci i prijatelji, doseljenici posle Drugog svetskog rata, kod kojih su izbeglice u prvi mah pronašle pribežište (Matijević, Tošić i Lukić, 2005.). 


\section{Rezultati i diskusija}

\subsection{Naselja u predelu}

\subsubsection{Spontana faza razvoja naselja}

Naselja na rečnoj terasi ili čak aluvijalnoj ravni, u 17. veku, imala su niz ograničenja u pogledu dostupnih resursa, ali i veću mogućnost da opstanu u vreme ratnih razaranja - najčešće su u šumi, daleko su od puteva, okružena su šumama, šikarama, vodotocima, barama i močvarama. Za takva naselja u Sremu, oslanjajući se na putopisce, D. Popović (1939.) navodi „...u jednom niskom i podvodnom terenu, gde kako naš narod iz tih krajeva kaže „mrtvaci plivaju“, jer se katkad pri kopanju zemlje već u dubini od jednog metra nailazi na vodu... ne može se govoriti o udobnim zemunicama, osim možda u višim terenima, na tzv „gredama“...". Oslanjajući se na putopisce i arheološka istraživanja A. Krstić (2005.) piše da se u 17. veku, između ostalog, na prostorima posavske i podunavske Srbije, znači i na prostoru istraživanja, stanovalo u kućama tipa brvnara ili bondručara, u kolibama od trske, ali i u kućama ukopanim u zemlju (poluzemunice), a da su se nad zemljom videli samo krovovi (slika 2.). O postojanju zemunica na ovim prostorima bi se moglo suditi po oikonimima, toponimima naselja u obrenovačkoj posavini. Nazivi naselja Krtinska i Urovci su etimološki povezani sa zemunicama.

Slika 2.

Sremsko selo u 17. veku.

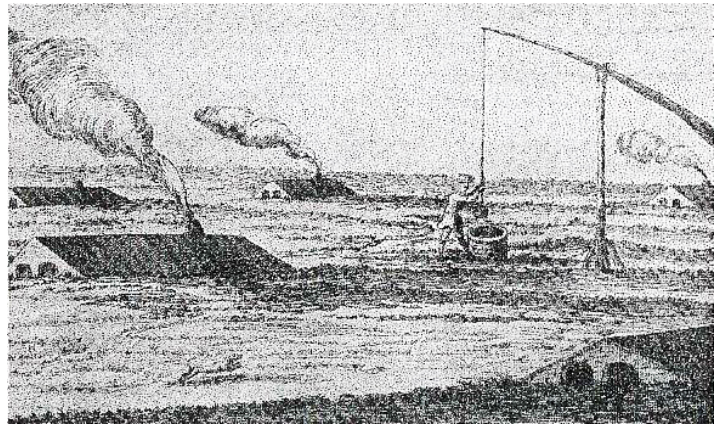

Izvor: Popović, 1939.

\subsubsection{Razuđeno-zbijeni ili potpuno zbijeni tip spontanih naselja Predela obrenovačke Posavine}

Prema austrougarskoj karti iz 1897. (prema Specijalnoj đeneralštabnoj karti iz 1893. godine) Predeo obrenovačke Posavine je grube granulacije - veliki i gotovo kompaktan šumski pokrivač, vlažne livade, ritovi i bare, na suvljim terenima naselja i oranice. S velikim stepenom sigurnosti se može tvrditi, na osnovu prostorne srukture, da su dominirali prirodni procesi odnosno, da je predeo pripadao prirodi bliskom 
tipu prema kriterijumu antropogene modifikacije. Naselja (Krtinska, Urovci, Zvečka, Zabrež, Grabovac, Skela ${ }^{4}$ ) su u šumi ili na ivici šume (Ratari, Ušće, Vrhovina i Rvati). Objekti u naselju stoje bez reda, različitog stepena zbijenosti, za razliku od Kunibertovih zapažanjima od pre pola veka ${ }^{5}$. Ovde se sporadično i postepeno primenjuje Uredba o ušoravanju naselja iz 1837. Zabeležen je nepravilan (više izodijametričan) i izdužen (razuđeni niza kuća oko uskog puta) oblik naselja (slika 3.). Izduženi oblik će kroz vreme koje dolazi prerasti u poseban obrazac naseljenosti.

Slika 3.

Naselja Krtinska i Urovci krajem 19. veka.

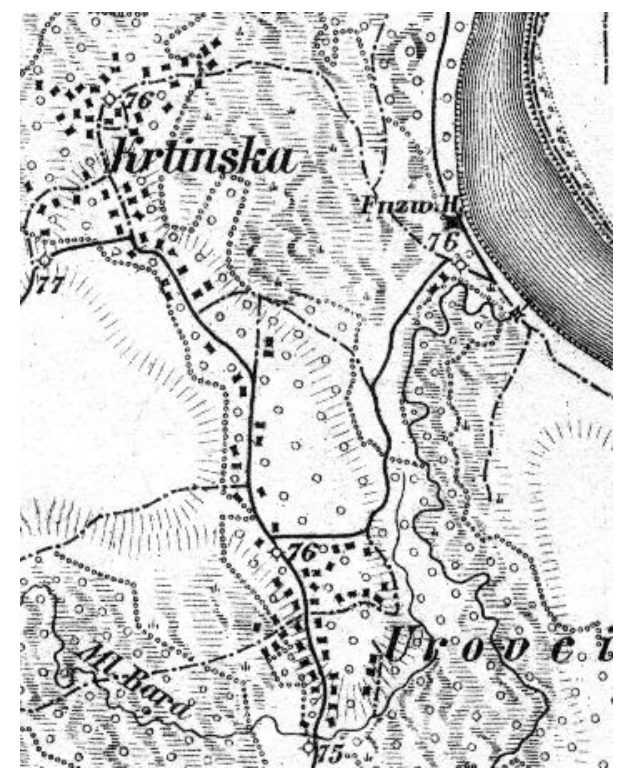

Izvor: Karte iz The Third Military Survey, Österreichisch-Ungarische Monarchie

Četrdesetih godina 20. veka (topografska karta iz 1935.) kao posledica agrarne reforme i opredeljenja za pravednijie zemljišno-posedovne odnose Predeo obrenovačke Posavine je visokog stepena prostorne heterogenosti pretežno fine granulacije - podtip tradicionalne kultivacije. Upitanju su mala seoska imanja oranice, polu-prirodna vegetacija u obliku šumaraka, živica, grupa drveća, livada, manjih i većih ritova i bara itd. Naselja pripadaju razuđeno-zbijenom ili potpuno zbijenom tipu spontanih naselja, po urbanističko-morfološkoj tipizaciji (Kojić, 1958.

${ }^{4}$ Na karti dva naselja nose isto ime - Skela, jedno je na visokoj obali, blizu Save, a drugo je udaljeno od Save.

5 O tome kako su izgledala naselja obrenovačke Posavine iz prve polovine 19. veka možda najbolje oslikava opis Kuniberta (Maksimović, 1962.): „svaka porodica sagradi sebi kolibu u šumi... daleko od glavnih drumova i putanja... Kolibe behu na odstojanju od dva do tri puškometa... i jedino po prokrčenom zemljištu moglo se zapaziti, usred ovih velikih šuma, da je čovek u nekom naseljenom mestu.“ 
prema Simonović, 1980.). Kućišta su nepravilna i nejednake veličine i uglavnom im je obezbeđen prilaz sa javnih saobraćajnica. Unutrašnje ulice su retke, krivudave i organizovane bez ikakvog sistema (Simonović i Ribar, 1993.).

U vremenu koje je dolazilo (topografske karte čiji je sadržaj dopunjavan 1951. i 1968.) u ovom predelu, delovi naselja sa raštrkanim kućama na javnim saobraćajnicama višeg reda postepeno se popunjavaju novim objektima. Formira se poseban tip tzv. drumska naselja (Simonović, 1980.) (slika 4. e, f). U ovom predelu imamo dve pojave drumskih naselja: Prva je „silaženje naselja na drum“, odnosno, preseljavanje domaćinstva uz veću saobraćajnicu i zauzimanje kvalitetnog poljoprivrednog zemljišta (Skela, Ratari), a druga pojava je poseban slučaj prethodne kada se građevinski reon nekog grada linijski širi nedozvoljenom gradnjom i postepeno stapa sa prigradskim selima (Obrenovac sa Zabrežjem, Zvečkom i Rvatima) (slika 5.).

Slika 4. (a,b,c i d)

Naselja s kraja 19. veka i iz 2006. godine: a i b - Platičevo; c i d - Obrež; e i f - Zvečka.

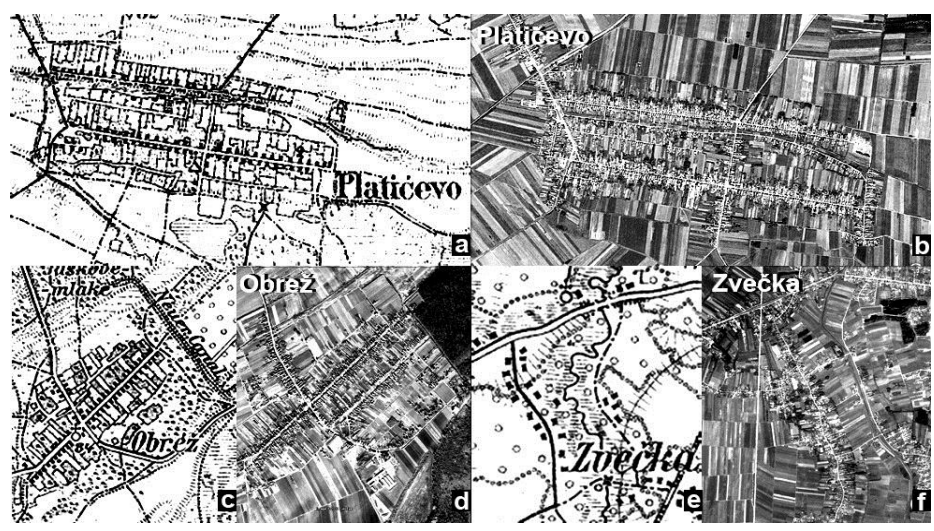

Izvor: Karte iz The Third Military Survey, Österreichisch-Ungarische Monarchie; satelitski snimci (Google Earth).

Slika 5. Položaj naselja i drumskih naselja (koridor obrazac) u dva posavska predela

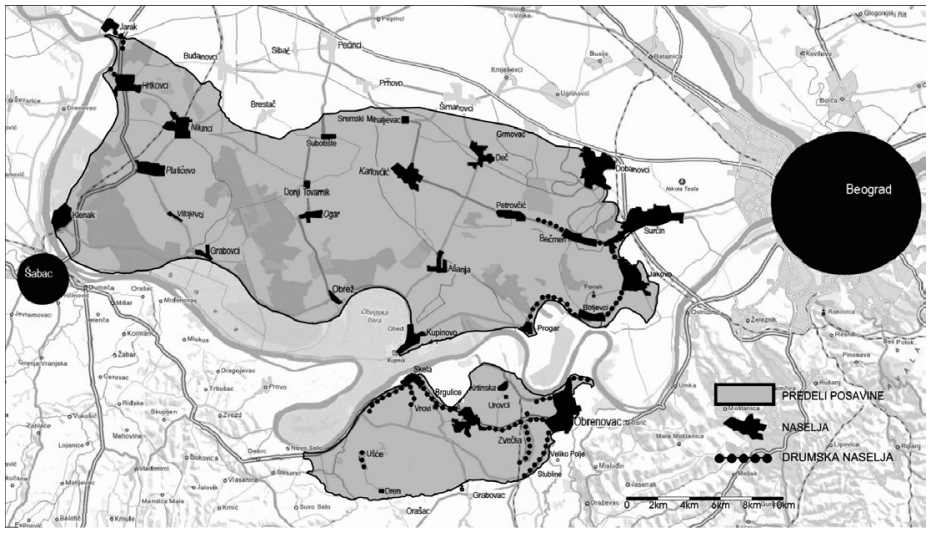

Izvor: http://www.serbiamap.net/index en.html 
Za nastajanje različitih struktura naselja posredno su uticali mnogi činioci, ali ono što je izvesno za ovaj predeo je politički uticaj, odnosno težnja vlasti (turske, austrijske, srpske) da naseobine budu zbijenije da bi se lakše mogle kontrolisati i naplaćivati porez. Jednom uspostavljeni građevinski reon nije dalje pratila planska regulativa jer je izvesno da je nepostojanje, ili bar ne koliko je neophodno, planski razvijene ulične mreže i infrastrukture uticalo na formiranje linijske strukture naselja na ovim prostorima još u 19. veku, za razliku od naselja u sremskom predelu.

Početkom 21. veka (satelitski snimci 2006.) na analiziranom delu obrenovačke Posavine prostorna struktura je nešto grublje granulacije kao posledica obavljene komasacije u jednom delu predela. Došlo je do ukrupnjavanja agrarnih površina, izgradnje kanalske i putne mreže, ali i uklanjanja elementa polu-prirodne vegetacije, isušivanja ritova i bara, što se može prepoznati kao podtip predela moderne kultivacije. Komasacija je obavljena tek 1988. godine prvi put za razliku od Srema (Republički geodetski zavod ŠRGZĆ, 2003.; Avramović, 2004.). Postupak komasacije nije uključio uređenje naselja (u atarima Zvečke, Obenovca, Urovaca, Krtinske, Brgulice, Ratara i Skele). To je bila prilika da se ispravi i pravilnije formira granica građevinskog reona, da se planira odnosno, predvide lokacije budućeg širenja naselja imajući u vidu postojeće neuređeno stanje.

S duge strane u ovom vremenskom preseku značajan prostor u predelu pripada energetsko-industrijskim zonama formiranim osamdesetih i devedesetih godina 20. veka. Pored dve termoelektrane u ovim zonama su velike deponije pepela od $400 \mathrm{i}$ 600 ha kao i razvodna postrojenja - dalekovodi. Položaj i veličina zona onemogućila je širenje naselja na potezu Ušće - Grabovac i Krtinska - Urovci. Pored toga, širenja nus-produkata eksploatacije uglja iz ovih zona ugrozili su komponente predela vazduh, vodu, zemljište itd. S druge strane, (prema Jokić i Petovar), zakonski okvir tog vremena vezan za eksproprijaciju posvećivao je mnogo više pažnje pravima predlagača i korisnika eksproprijacije nego pravima subjekata eksproprijacije, čime je direktno dovođena u pitanje društvena održivost. Navedeni uticaji su se direktno odrazili na demografsku stagnaciju naročito izraženu kroz priraštaj stanovnika u periodu 1992.-2002. godine.

Naime, zapaženo je da se u poslednjoj dekadi 20. veka broj stanovnika u opštini nije mnogo izmenio (tabela 1.), bez obzira što je to bilo vreme velikog priliva izbeglica gotovo u sve delove Srbije, kao u sremskom predelu.

Tabela 1.

Promena i priraštaj stanovnika u opštini Obrenovac za period 1971.-2002. (prema Dragićević i Karić, 2008.)

\begin{tabular}{|c|c|c|c|c|c|c|c|}
\hline \multirow{2}{*}{ Opština } & \multicolumn{3}{|c|}{ Broj stanovnika u godinama: } & \multicolumn{3}{c|}{ Priraštaj stanovnika u periodu: } \\
\cline { 2 - 7 } & 1971. & 1981. & 1991. & 2002. & $1972 .-1981$. & $1982 .-1991$. & $1992 .-2002$. \\
\hline Obrenovac & 53.260 & 62.612 & 70.234 & 70.974 & 9.352 & 7.622 & 740 \\
\hline
\end{tabular}


U isto vreme primetan je rast stanovništva kako u samom Obrenovcu tako i u prigradskim naseljima, i opadanje onih na periferiji opštine kao posledica otvaranja novih radnih mesta u formiranim energetsko-industrijskim zonama (Dragićević i Karić, 2008.) - migracija stanovništva unutar opštine ${ }^{6}$. građevinski reon grada se spontanim širenjem spojio sa prigradskim selima i formirao jedan novi tip predela suburbane strukture u okviru granica Predela obrenovačke Posavine. Proces suburbanizacije predela započeo je početkom 20. veka i povezan je sa razvojem železničkog, a posle Drugog svetskog rata sa razvojem automobilskog saobraćaja. Pristupačnost omogućena novim načinom prevoza, nova radna mesta, nerešeno stambeno pitanje i nepostojanje tržišta stanova ili previsoka cena istih, postali su najvažniji faktori u promeni ovog predela. Sve ovo zajedno sa niskim stepenom kontrole pogodovalo je pojavi bespravne izgradnje na poljoprivrednom zemljištu kao jeftinijem na periferiji Obrenovca, van kontinualno izgrađenog gradskog područja, prevashodno uz magistralne i lokalne puteve, a uz postojeća naselja.

\subsubsection{Ušorena naselja u Predelu donjeg Srema}

Naselja u Sremu su se u osnovi spontano razvijala do reformi od sredine 18. veka, a posebno do donošenja urbara 1756. godine. Uvođenjem urbara došlo je do primetnog razvitka socijalnih i ekonomskih prilika u civilnom delu Sremske županije. Ovaj razvoj prati početak kontinuiranog uređenja šire teritorije posmatranog područja prevashodno zbog potrebe za regulisanje poseda, u smislu premeravanja i kategorizacije, kao i uređivanja naselja, izgradnja puteva itd. (Gavrilović, 2007.). Analizirani predeo (pripadao je graničarskom Sremu) je takođe, bio obuhvaćen procesom urecenja prostora - došlo je do izgradnje puteva i reurbanizacije većeg broja naselja, dok se neka stara naselja i tvrđave u u ovom periodu ne obnavljaju (Krstić, 2005.). Poznato je da se ušorena naselja formiraju rekonstrukcijom starih ili kombinacijom starih naselja (delimično porušenih) i novih slobodnih prostora. Ušorena naselja se formiraju po ugledu na planska s tom razlikom što za njih nisu rađeni planovi. Proces stavljanja u šor, ušoravanje naselja podrazumeva direktan rad na terenu po određenim principima. Ulice se prosecaju kroz naselje ili van naselja, po ortogonalnoj šemi. Uz prosečene ulice se postavljaju kućišta. Kućišta su u nizu, pravougaonog oblika sa stambenim objektom prema ulici, a ekonomskim ka unutrašnjosti. Po ugledu na planska naselja i ovde su ulice široke, kućišta više-manje pravilna, kao i raspored i organizacija stambenih i ekonomskih objekata (Simonović, 1980.; Gostović, 1989.).

Analizom austrougarske topografske karte (1881.-1887.) uočeno je da predeo nosi sve odlike predela tradicionalne kultivacije, strukturno nešto grublje granulacije smenjuju se veći kompleksi šuma, šikare, pašnjaci i utrine, bare i močvare, zabareni vodotoci, ali i ušorena naselja, putna mreža, veći kanali, oranice, voćnjaci i vinogradi itd. Dalje, uočeno je da je uspostavljena mreža ulica u naseljima, vrlo često mnogo većeg kapaciteta od potreba koje iziskuju postojeća kućišta (slika 4.a). Ovakva ulična mreža po pravilu opkoljava neizgrađene blokove na periferiji naselja, ali i definiše unutrašnjost naselja približno ortogonalnom obrascu, bez obzira na razvijenost građevinskog reona. Ovako formirana mreža ulica, pored osnovne povezujuće

$\mathbf{6}$ Teritorija gradske opštine Obrenovac je mnogo veća od istraživanog predela. 
uloge ima ulogu i razdvajnja građevinskog reon od zajedničkih pašnjaka i poljoprvirednih parcela. Ovakvim postupkom uspostavljen je obrazac kojim je omogućeno da nova kućišta mogu biti postavljena kako unutar tako i u periferiji naselja, čime je ostvarena osnovna pretpostavka za veći stepen kontrolisanog razvoja naselja.

Razvoj određenih privrednih grana uticao je na građevinski reon u analiziranom vremenskom periodu. Evidentirano je da su se sva mesta (Klenak, Platičevo, Nikinci) pored železničke pruge (izgrađena 1901.) više razvijala, postajala veća, po pravilu od onih koja su udaljenija od pruge.

Četrdesetih godina 20. veka ovaj predeo je takođe grublje granulacije, ali je u odnosu na prethodni vremenski presek, a kao rezultat prvih komasacija, sa mnogo manje šikara i utrina, bara i močvara, gušćom mrežom kanala, većim površinama pod oranicama i mrežom poljoprivrednih puteva. Kod najvećeg broja sela tokom analiziranog perioda nije došlo do bitnih izmena izuzev, premeštanje Vitojevaca sa aluvijalne ravni na rečnu terasu. Promene su se, posle sprovedenih meliorativnih radova i uklanjanja vlažnih depresija, najčešće i dalje prilagođavale morfološkim karakteristikama terena i uspostavljenom obrascu naselja. Ove promene imaju za rezultat širenje naselja: uz ulice na obodu naselja, a ređe uz puteve koji vode iz naselja (slika 4.d); uz novoformirane ulice, kako na obodu tako i unutar naselja itd. (slika $4 . \mathrm{a}$ i b).

Početkom 21. veka Predeo donjeg Srema je zadržao strukturno grubu granulaciju, ali ga prati proces homogenizacije prostora karakterističan za predele gde je završena komasacija i dominira moderna intenzivna poljoprivreda - velike parcele pod oranicama sa gustom mrežom kanala i poljoprivrednih puteva, ali i sačuvanim većim kompleksima šuma itd. U proteklom periodu, naročito posle Drugog svetskog rata, u predelu se javlja ekonomski motivisana migracija stanovništva - raste broj u naseljima bližim Beogradu (Bečmen, Surčin, Jakovo, tab.), dok u udaljenijim stagnira (Kupinovo, Platičevo, Boljevci, tabela 2.).

Tabela 2.

Uporedni pregled broja stanovnika u Predelu donjeg Srema (Republički zavod za statistiku, 2004.)

\begin{tabular}{|c|c|c|c|c|c|c|}
\hline \multirow{2}{*}{ Godina } & \multicolumn{7}{|c|}{ Mesto } \\
\cline { 2 - 7 } & Bečmen & Surčin & Jakovo & Kupinovo & Platičevo & Boljevci \\
\hline 1931. & 974 & 3.502 & 2.015 & & 2.802 \\
\hline 1961. & 1.195 & 6.160 & 2.624 & 2.220 & 2.726 & 3.641 \\
\hline 1971. & 1.357 & 10.550 & 3.123 & 2.057 & 2.824 & 4.008 \\
\hline 1981. & 2.494 & 12.575 & 4.619 & 2.002 & 2.812 & 3.974 \\
\hline 1991. & 3.020 & 11.826 & 5.483 & 2.009 & 2.809 & 4.284 \\
\hline 2002. & 3.525 & 14.292 & 6.066 & 2.047 & 2.760 & 4.056 \\
\hline
\end{tabular}


Dostupnost grada kroz dobru saobraćajnu povezanost i niže cene zemljišta u naseljima su bitni uzroci promena, kao i u suburbanom predelu Obrenovca. Isto tako, kao u slučaju Obrenovca, slabo poštovanje planske regulative i nizak stepen kontrole s jedne strane i visok stepen uticaja širenja i ekonomskog razvoja Beograda, a s kraja 20. veka i izbegličke migracije (tabela 3.) uticali su na pojavu bespravne izgradnje na poljoprivrednom zemljištu i uočljivije širenje naselja, posebno na području dnevnih migracija stanovništva (Surčin, Jakovo i Bečmen).

Tabela 3.

Broj izbeglica iz Hrvatske i Bosne i Hercegovine po opštinama u Predelu donjeg Srema i njihovo učešće u ukupnom stanovništu.

\begin{tabular}{|c|c|c|c|c|}
\hline \multirow{2}{*}{ Opština } & $\begin{array}{c}\text { Broj } \\
\text { izbeglin* }\end{array}$ & $\begin{array}{c}\% \text { u ukupnom } \\
\text { staništvu }\end{array}$ & $\begin{array}{c}\text { Broj } \\
\text { izbeglih* }\end{array}$ & $\begin{array}{c}\text { u ukupnom } \\
\text { staništvu }\end{array}$ \\
\cline { 2 - 6 } & \multicolumn{2}{|c|}{1991.} & 3.763 & 17,5 \\
\hline \multirow{2}{*}{ Pećinci } & 217 & 1,0 & 13.659 & 23,0 \\
\hline Ruma & 1.277 & 2,3 & $21.800^{* * *}$ & $11,4^{* *}$ \\
\hline Zemun & & & & \\
\hline
\end{tabular}

"Podaci dobijeni od UNHCR-a (prema Lukić, 2005.)

"Podaci za 2002. (prema Rašević i Penev, 2006.)

Spontano širenje takvih naselja se „preliva“ sa ulične infrastrukture na putnu infrastrukturu, što ima za rezultat formiranje linijskog niza stambenih objekata na potezu od Progara preko Boljevaca do Jakova (i Surčina) i na potezu Petrovčić preko Bečmena do Surčina (slika 5.).

\subsection{Prostorni obrasci}

Širenje naselja na nivou predela na istraživanom području ogleda se u formiranju tri prostorna obrazaca:

- koridor obrazac;

- unutrašnji obrazac prostornog širenja (unutrašnja eksplozija)

- ivični obrazac prostornog širenja (eksplozija)

Koridor obrazac naseljenosti se najčešće razvija duž glavne saobraćajnice - puta, usled antropogenog ili prirodnog (blizina vodotoka, bara, šume itd.) ograničenja za druge obrasce. Antropogeno ograničenje je najčešće nepostojanje mreže ulica, a s druge strane naselje ima potencijala za razvoj pre svega, svojim položajem u predelu. Agro-industrijski objekti, u formi za selo megastrukturnih dimenzija, uz glavnu saobraćajnicu na ivici naselja su najčešće prepreka za ovaj oblik širenja u donjem Sremu. Treba istaći naselje Zvečku koje pripada ovom obrascu, ali sa specifičnim, zrakastim razvojnim oblikom u pravcu tri kraka. Ovo naselje je u ekspanziji zbog blizine Obrenovca, i širi se duž glavnih saobraćajnica. Takva matrica naselja uočena 
je još na kartama iz 19. veka (slika 3.). Poslednjih decenije koridor obrazac je u određenom stepenu karakterističan za oba predela (slika 5.).

Naselje sa unutrašnjim obrascem prostornog širenja nastaje procesom pogušćavanja (ispunjavanjem) unutrašnjosti građevinskog reona sa novim kućištima pored već uspostavljenih ulica. Do ovog obrazaca dolazi usled prirodnih ili antropogenih ograničenja za širenje naselja kao kod prethodno iznetog obrasca, zbog prethodno uspostavljene mreže unutrašnjih ulica i puteva, te usled visokih potencijala za razvoj sela (prirodni i stvoreni uslovi). Ovaj obrazac je karakterističan za ušoreni tip naselja donjeg Srema (slika 4.).

Naselja sa ivičnim obrascem prostornog širenja (eksplozija) imaju dovoljno prostornih mogućnosti za razvoj, tj. najčešće nemaju prirodnih ograničenja, dok su ograničenja antropogenog porekla sporadična. Ova naselja su najčešće u ekspanziji zbog blizine nekog većeg mesta ili grada (Hrtkovci, Surčin, Jakovo). Za širenje naselja se najčešće koristi postojeća ivična ulična mreža, a u nedostatku ove koriste se poljoprivredni putevi naslonjeni na uličnu mrežu. Ovom obrascu, često prethodi proces unutrašnjeg pogušćavanja koje po pravilu zbog nedovoljnih prostornih mogućnosti u odnosu na potrebne kapacitete, prerasta u pojavni oblik širenja po obodu. Ivični obrazac prostornog širenja je karakterističan pre svega za ušoreni tip naselja u Predelu donjeg Srema.

\section{Zaključak}

Analizirani predeli i naselja obrenovačke Posavine i donjeg Srema do druge polovine 18. veka su vrlo slični po prirodnim i društvenim karakteristikama, bez obzira na uticaje kroz koje su prošli. naselja su pripadala prema genezi spontanom tipu i bila slična po morfološkoj strukturi terena izabranih lokacija. Kontekst u kojem su se javljala ovakva naselja pripada prirodi bliskim predelima.

Na prostoru današnjeg Srema u drugoj polovini 18. veka Austrija je sprovela suštinske reforme u redefinisanju agrarnih odnosa i uređenja prostora. Rezultat takvih formalnih procesa reurbanizacije je formiranje ušorenih naselja u predelu podtipa tradicionalne kultivacije, prema savremenoj klasifikaciji. U obrenovačkoj Posavini u periodu turske vlasti zadržan je spontani vrlo razuđeni tip naselja u prirodi bliskom predelu. Tako su u dva analizirana prostora uspostavljene različite kulturne i uopšte društvene vrednosti kao posledica vladavine dve različite države - Otomanskog i Austrijskog carstva.

U četrdesetim godinama 19. veka, u vremenu vezanom za oslobađanje od turske vladavine i želje za sprovođenjem niza reformi, javlja se neformalni proces reurbanizacije na prostoru mlade srpske države kome pripada i obrenovačka Posavina. Posledica takvih procesa je sporadično formiranje razuđeno-zbijenog do potpuno zbijenog tipa spontanih naselja u još uvek prirodi bliskom tipu predela. 
Od dvadesetih godina 20. veka analizirani prostor pripada istoj državi odnosno, predeli se nalaze pod istim političkim i kulturnim uticajem, ali su svejedno naselja široko uzevši, zadržala dva, međusobno različita strukturna tipa sa različitim stepenom uređenosti. Uspostavljena organizacija naselja u Predelu donjeg Srema još u drugoj polovini 18. veka, omogućila je kroz vreme bolje kontrolisanje spontane izgradnje i viši stepen uređenosti (unutrašnji i ivični obrazac prostornih promena) uprkos bespravnoj izgradnji, a sprovedene komasacije su uticale na transformaciju predela od podtipa tradicionalne do podtipa moderne kultivacije. U odnosu na prostor sa druge strane reke, u obrenovačkoj Posavini je, između ostalog, i zbog stihijskog širenja i bespravne izgradnje prevashodno uz saobraćajnice višeg reda (koridor obrazac) došlo do spajanja Obrenovca sa prigradskim selima. Rezultat takvih procesa je formiranje novog suburbanog predela. Drugi i veći deo ovog predela, pored bespravne izgradnje na poljoprivrednom zemljištu, karakteriše i proces eksproprijacije za potrebe energetsko-industrijske zone sa svim svojim posledicama po lokalno stanovništvo i sredinu, te delimična komasacija iz 1988. što sve zajedno opredeljuje ovaj deo predela kao podtip predela mešovite kultivacije. Međutim, u poslednjih dve decenije procesi urbanizacije predela su smanjeni jer je zabeležen izrazito mali porast stanovništva, prevashodno zbog stanja životne sredine, ali i zbog fenomena „grada na ivici“, odnosno pozicije Obrenovca u odnosu na Beograd.

Poslednjih petnaest godina na području Srema u delu analiziranog predela se javljaju procesi karakteristični za prostor u obrenovačkoj Posavini - stihijsko širenje i bespravna izgradnja uz put. Takvi procesi nastaju kao posledica naglog mehaničkog povećanja stanovništva u vremenu nedovoljnog poštovanja planske regulative, nedovoljnog poštovanja uspostavljenih vrednosti i tradicionalnog načina života koji traju gotovo 250 godina, a upućivali su na bolju organizaciju i funkcionisanje u prostoru. Očigledno da svaka nagla promena sa širokim dometom delovanja ostavlja na predeo velike posledice, jer sistem u obliku slabe državne kontrole ne uspeva da se odupre spontanom i stihijskom uticaju bez obzira na uspostavljene vrednosti i tradiciju.

\section{Zahvalnica}

Ovaj rad je realizovan u okviru projekta „Istraživanje klimatskih promena na životnu sredinu: praćenje uticaja, adaptacija i ublažavanje" (43007) koji finansira Ministarstvo za prosvetu i nauku Republike Srbije u okviru programa Integrisanih $i$ interdisciplinarnib istraživanja za period 2011.-2014. godine. 


\section{Literatura}

1. **** (1881-1897). Budjanovci, Kupinovo, Mitrowitz. The Third Military Survey, Österreichisch-Ungarische Monarchie, Kroatien-Slawonien, 1867-1887, 1:75,000. Izvor: Narodna biblioteka Srbije. Beograd

2. **** (1893). G.2. Obrenovac, 1:75,000, Specijalna đeneralštabna karta Kraljevine Srbije. Geografsko odeljenje Glavnog Đeneralštaba. Beograd

3. *** (1935). Obrenovac, listovi 1, 2,3 i 4. Topografska karta, razmera 1:50,000. Vojno-geografski institut. Beograd

4. Antrop, M., (2005). Why landscapes of the past are important for the future. Landscape and Urban Planning, 70 (1-2):21-34.

5. Avramović, M. (2004). Uređenje zemljišne teritorije komasacijom u Republici Srbiji. Geodetska služba, 33 (1):54-68.

6. Bogojević, Đ. (1928). Agrarna reforma. Jubilarni zbornik života $i$ rada Srba, Hrvata i Slovenaca 1918-1928. Beograd: Matica živih i mrtvih.

7. Ćurčić, S. (2001). Naselja Srema - geografske karakteristike. Novi Sad: Matica srpska.

8. Dragicević, S. i Karić, I. (2008). Geoprostorne karakteristike gradske opštine Obrenovac (skracena verzija). Pregledano 18.9.2010. (http://www.ekofond.org. rs/pdf/o obrenovcu.pdf).

9. Đokić, V., Marošan, S. (2008). New model of land consolidation and rural development in Serbia. Spatium, 17/18:61-67.

10. Forman, R., Godron, M. (1986). Landscape ecology. John Willey \& Sons. New York.

11. Gaćeša, N. (2007). Privredni razvitak Srema u 19. i 20. veku, Iz: Maticki M. (ur.). Srem kroz vekove. Zbornik radova. Beograd-Beočin.

12. Gavrilović S. (2007). Feudalni posedi u Sremu 18. veka, Iz: Maticki M. (ur.). Srem kroz vekove. Zbornik radova. Beograd-Beočin.

13. Gavrilović, S. (1960). Urbarijalno pitanje u Sremskoj županiji sredinom XVIII stoleća. Zbornik Matice srpske za društvene nauke, sv. 27, 5-32.

14. Gavrilović, S. (2005). Nove vojne granice u Sremu, Potisju i Pomorišju kao primarne oblasti migracija u Rusko carstvo u 18. Veku. Seoba Srba u Rusko carstvo polovinom 18. veka. Zbornik radova sa međunarodnog naučnog skupa u Novom Sadu, 7-9. maja 2003, Novi Sad, 2005, 19-26.

15. Gostović, M. (1989). Uređenje seoske teritorije. Beograd: Građevinski fakultet.

16. Jokić, V., Petovar, K. (2010) Procena uticaja na socijalni razvoj u projektima otvaranja i širenja površinskih kopova, in: Nenad Spasić, Jasna Petrić (eds.). Prostorni, socijalni i ekološki aspekti održivog razvoja u velikim ugljenim basenima. Tematski zbornik, izdanje br. 61. Beograd: Institut za arhitekturu i urbanizam Srbije:69-84.

17. Jovančević, S. (2010). Modernization of Serbian society in 19th century. Politička revija, 9 (1):411-435.

18. Kristiánová, K. Adamková, J. (2010). Slovak agricultural landscape - transition responses. ITU $A d Z, 7$ (2):121-132.

19. Krstić, A. (2005) Seoska naselja u Podunavlju i Posavini Srbije i južne Ugarske u 15. i prvoj trećini 16. veka. Istorijski časopis, 52:165-194. 
20. Krueger R. (2002). Mediating Progress in the Provinces: State-Building versus Citizen-Making in the Agrarian Societies of 18th Century Bohemia. Robert Schuman Centre for Advanced Studies. European University Institute Badia Fiesolana. San Domenico (FJ), Italy.

21. Kulauzov, M. (2008). Postanak, razvitak i razvojačenje Vojne granice Austrijske monarhije. Zbornik Matice srpske za društvene nauke, 125:141-147

22. Lukić V. (2005). Izbegličke migracije iz Bosne i Hercegovine u Beogradu. Geografski institut "Jovan Cvijić". Beograd: SANU, knjiga 66.

23. Maksimović B. (1962). Urbanizam u Srbiji. Beograd: Građevinska knjiga.

24. Matijević, D., Tošić, B., Lukić, V. (2005). Uticaj migracija na populacione i funkcionalne promene sremskih opština. Glasnik Srpskog geografskog društva, 85 (1):111-120.

25. Matvejev, S. i Puncer, I. (1989). Karta bioma: Predeli Jugoslavije i njihova zaštita. Prirodnjački muzej, Beograd: Posebna izdanja 36:1-76.

26. Menković LJ., M. Košćal (2003). Geomorfološka karta Srbije 1:500.000. Beograd: Geozavod - Gemini, Smederevska Palanka: Magic Map.

27. Metzger, M.J., Bunce, R.G.H., Jongman, R.G.H., Mücher, C.A. and Watkins, J.W. (2005). A climatic stratification of the environment of Europe, in: Wascher, D.M. (ed). 2005. European Landscape Character Areas - Typologies, Cartography and Indicators for the Assessment of Sustainable Landscapes. Final Project Report as deliverable from the EU's Accompanying Measure project European Landscape Character Assessment Initiative (ELCAI), funded under the 5th Framework Programme on Energy, Environment and Sustainable Development (4.2.2):5-8.

28. Milošević, S. (2008). Agrarian issue: 'Sacred issue': The general ideological scope of interwar agrarian reform in Yugoslavia. Tokovi istorije, 1/2:149-171.

29. Pejanović, R. V., \& Tica, N. (2005). Agrarian problem in the process of transition in the Republic of Serbia. Letopis naučnih radova Poljoprivrednog fakulteta, 29 (1):210-221.

30. Popović, D. J. (1939). Vojvodina. Tom 2. Istorisko društvo u Novom Sadu

31. Rašević, M., Penev, G. (2006). Demografska slika Beograda na početku 21. veka. Stanouništvo, 44 (1):81-96.

32. Republički geodetski zavod (2003). Komasacija u Srbiji. Monografija: Republički geodetski zavod, Beograd.

33. Republički zavod za statistiku (2004). Uporedni pregled broja stanounika 1948, 1953, 1961, 1971, 1981, 1991 i 2002 -podaci po naseljima. Beograd

34. Roksandić, D. (2007). Posavska krajina/granica od 1718. do 1739. godine. Ekonomska i ekohistorija Vol. 3, Br. 3, 62-82 Zagreb - Samobor.

35. Simon, H.A. (1973). The Organization of Complex Systems. New York: George Braziller:1-27.

36. Simonović Đ., Ribar M. (1993). Uređenje seoskib teritorija i naselja: urbanizacija sela. Beograd: Građevinska knjiga

37. Simonović, Đ. (1980). Uređenje seoskih teritorija i naselja. Beograd: Građevinska knjiga.

38. Stephenson, J., (2008). The Cultural Values Model: An integrated approach to values in landscapes. Landscape and Urban Planning, 84:127-139. 
S. Radulović, A. Bobić, M. Sekulić, M. Bobinac: Uticaj istorijskih i političkih promena...

39. Van Eetvelde V., Antrop M., (2009). Indicators for assessing changing landscape character of cultural landscapes in Flanders (Belgium). Land Use Policy, 26:901910. 
Professional Paper

\title{
Stojanka Radulovic
}

University of Belgrade-Faculty of Forestry, Department of Landscape Architecture and Horticulture e-mail: stojanka.radulovic@sfb.bg.ac.rs

Aleksandar Bobic

University of Belgrade-Faculty of Forestry and Faculty of Architecture

e-mail: aleksandar.bobic@sfb.bg.ac.rs

Mirjana Sekulic

University of Novi Sad-Faculty of Technical Sciences, Department of Architecture and Urban Planning e-mail: sekulic.mirjana55@gmail.com

\section{Martin Bobinac}

University of Belgrade-Faculty of Forestry, Department of Forestry

e-mail: martin.bobinac@sfb.bg.ac.rs

\section{Impact of historical and political changes on the development of settlements in two Posavina landscapes from 18th century till today}

\begin{abstract}
This paper studies the impact of historical and political changes on the development of settlements in some Posavina landscapes on the territory of Serbia in the time range from 18th century till today. It analyzes the transformation of the two, by their natural characteristics and ethnic composition, very similar landscapes - the Lower Srem and Obrenovac Posavina, but at the same time very different landscapes by the historically established cultural and social values of the Ottoman and the Austrian (Austro-Hungarian) political influence.

The focus is on a comparative and contrastive analysis of plans, regulations, planning practices and key historical and political events related to the observed area from 18th century till today. The research also indicates that during the settlement reurbanisation on the observed territory, two mutually different and recognizable spatial patterns of settlements have been established, with special features and differences in topography and organization, which have largely remained as such until today, despite the same social and political order they belonged to during the 20th century. It is concluded that a higher degree of organization of settlements in one area over another has been achieved, thanks to, among other things, the formation of the wider spatial infrastructure and settlement regulation - the network of streets and undeveloped blocks, which made it possible to manage the development through time and prevent spontaneous settlement construction. However, during the period of political and economic transition of Serbia there's been illegal construction developed in the form of road settlements, regardless of the established values and traditions. It can therefore be concluded that a rapid and mechanical population growth in the second half of 20th century, together with lack of flats and/or flat market, lack of plans and/or disrespect of planning regulations and a low level of social sustainability, had an impact on the landscape. The system of weak state control of legislation regarding human activities and relevant actors in the studied area, failed to resist the uncontrolled spread of settlements.
\end{abstract}

Key words: landscape, spontaneity, settlement, spatial pattern, social value. 